九州大学学術情報リポジトリ

Kyushu University Institutional Repository

\title{
NOTES ON REMARKABLE COLOR VARIATIONS OF CRYPTOCEPHALUS AMICULUS BALY OCCURRING ON MT. HIKO AND ITS ADJACENT AREAS
}

Kimoto, Shinsaku

https://doi.org/10.5109/2360

出版情報: ESAKIA. 7, pp.71-73，1969-01-31. Hikosan biological laboratory, Faculty of Agriculture, Kyushu University バージョン :

権利関係 : 


\title{
NOTES ON REMARKABLE COLOR VARIATIONS OF CRYPTOCEPHALUS AMICULUS BALY OCCURRING ON MT. HIKO AND ITS ADJACENT AREAS*
}

\author{
BY \\ Shinsaku Kıмото
}

A small Chrysomelid beetle described by Baly a s Cryptocephalus amiculus which was originally described from Nagasaki has been widely recorded from Hokkaido, Honshu, Shikoku, Kyushu to E. Siberia. In 1964, the population of the so-call amiculus occurring in Honshu and Hokkaido was separated from the true amiculus as an independent species and named as Cryptocephalus kiyosatonus Kimoto. This species extremely resembles C. amiculus Baly and is almost inseparable from the latter species except the male genitalia.

In these several years, I have examined good numbers of additional specimens of Cryptocephalus amiculus Baly from Mt. Hiko and its adjament areas and came to the conclusion that there are considerable variations in the pronotal and elytral markings.

In the course of this study, I am indebted to Prof. K. Yasumatsu, Kyushu University, for his kind guidance and encouragement. I am also indebed to $\mathrm{Mr}$. H. Sasaji (=Kamiya), Fukui University, Prof. Y. Wada, Nagasaki University, Mr. Y. Miyatake, Osaka Museum of Natural History, for their kindness in giving me this interesting material.

1. Variation of pronotal and elytral markings

a) Pronotum and elytra shining black (nominate form).

Specimen examined : Hiraodai, Fukuoka Pref. (1 ex., 6. vii. 1952, K. Yasumatsu leg.).

b) Pronotum black with anterior and posterior corners of lateral margins brownish, elytra blackish with apical portion brownish.

Specimen examined : Mt. Ichifusa, Kumamoto Pref. (1 ex., 30. vii. 1952, S. Kimoto leg.).

c) Pronotum black with a pair of subbasal markings and lateral margins narrowly brownish, elytra black with latero-subbasal markings and apical portion brownish.

* Contribution Ser. 2, No. 43. Hikosan Biological Laboratory, Kyushu University, Hikosan. 
Specimens examined: Mt. Sobo, Ôita Pref. (5 exs., 24. vii. 1956, H. Kamiya leg.).
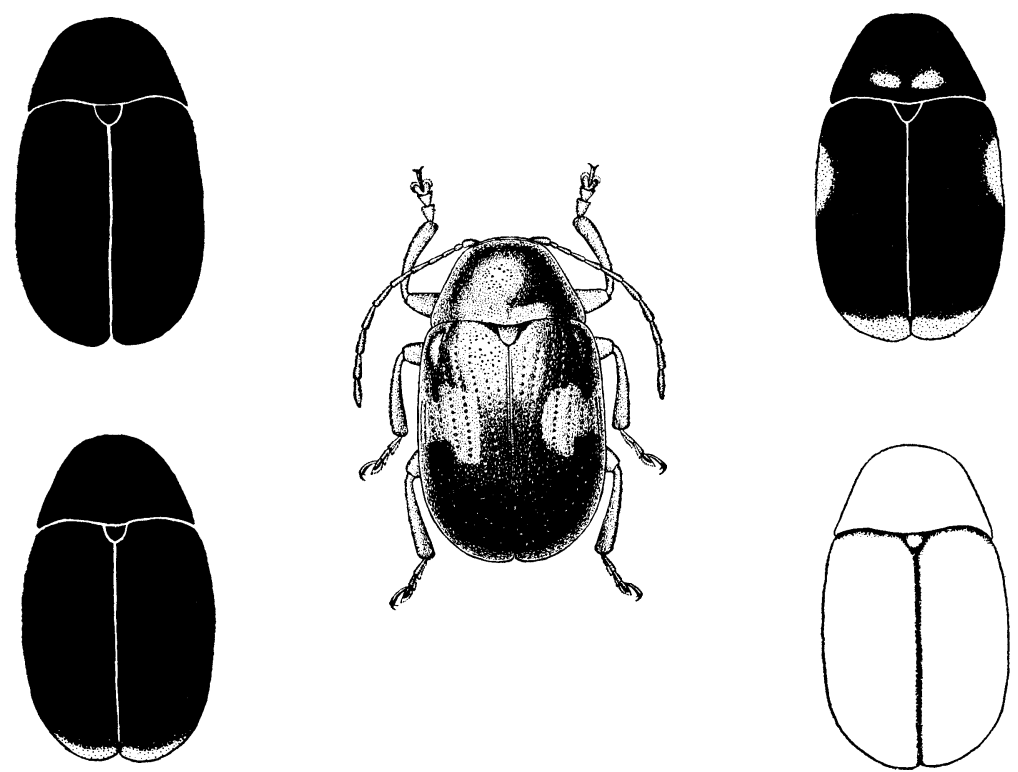

Fig. 1. Variations of pronotal and elytral markings of Cryptocephalus amiculus Baly.

d) Pronotum black with a pair of subbasal markings and lateral margins brownish, elytra black with a subbasal transverse marking and apical portion brownish.

Specimens examined : Mt. Hiko, Fukuoka Pref. (2 exs., 5. viii. 1951, K. Yasumatsu leg.). Mt. Sefuri, Fukuoka Pref. (1 ex., 11. viii. 1955, H. Kamiya leg.).

e) Pronotum reddish brown to yellowish brown, elytra yellowish brown with sutural and basal margins blackish.

Specimens examined : Mt. Kujû,Ôita Pref. (4 exs., 18. vii. 1958, Y. Miyatake leg.).

\section{Comparison with Cryptocephalus fulvus Goeze}

Up to the present, color variation of amiculus Baly belonging to the type e has not been known. This type of specimen closely resembles fulvus Goeze, but is separable in having the following characters.

i) fulvus Goeze: Elytral punctation strong even in subapical portion, pronotum almost impunctate, dorsal prolongation of aedeagus long and a pair of lateral pieces narrower and truncate apically.

ii) amiculus Baly : Elytral punctation much finer and obsolete on apical 
portion, punctation of pronotum stronger than fulvus, dorsal prolongation of aedeagus short and a pair of lateral pieces wider.
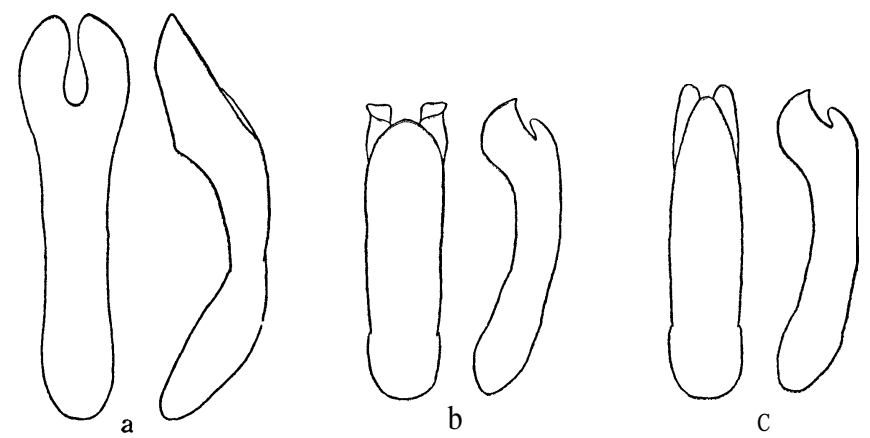

Fig. 2. Male genitalia. a, Cryptocephalus amiculus Baly ; b, C. fulvus Goeze ; c, C. kiyosatonzrs Kimoto. 